\title{
Sustaining the Women, Peace, and Security Agenda: The Role of UN Peacekeeping in Africa
}

\author{
Lisa Sharland
}

\section{INTRODUCTION}

In May 2000, the Government of Namibia hosted a workshop focused on mainstreaming a gender perspective into the work of multidimensional peace support operations. The workshop set out to examine practical ways that the United Nations (UN) and member states could strengthen the principles of gender equality, through the vehicle of peace operations, as a means to ensure a "situation of political stability in which women and men play an equal part in the political, economic, and social development of their country." It was a timely discussion in Namibia, as the workshop marked ten years since the country had hosted a UN peacekeeping mission. ${ }^{2}$ One outcome from that workshop was the Windhoek Declaration and Namibia Plan of Action on Mainstreaming a Gender

L. Sharland $(\bowtie)$

Head of International Program, Australian Strategic Policy Institute, Yass, NSW, Australia

e-mail: lisasharland@aspi.org.au

(C) The Author(s) 2021

T. McNamee and M. Muyangwa (eds.),

The State of Peacebuilding in Africa, https://doi.org/10.1007/978-3-030-46636-7_7 
Perspective in Multidimensional Peace Operations. ${ }^{3}$ That outcome document contributed to the eventual adoption of the UN Security Council's first resolution (UNSCRI325) on women, peace, and security (WPS) in October 2000. ${ }^{4}$ As such, the council recognized that women's equality and security was linked to the maintenance of international peace and security. UN peace operations had an important role to take forward the agenda in areas where they were deployed.

More UN peacekeeping missions have deployed to Africa than any other continent. As of October 2019, seven UN peacekeeping missions were deployed on the African continent, with more than 80,000 blue helmets serving across large multidimensional missions in contexts such as Mali, the Democratic Republic of the Congo, South Sudan, Sudan, the Central African Republic, and Western Sahara. Two long-term missions, in Liberia and Côte d'Ivoire, recently transitioned and exited the country after nearly fifteen years.

Although there has been progress with women's political representation in Africa, women remain disadvantaged in many parts of the continent due to patriarchal attitudes and cultural norms. Women have disproportionately borne the consequences of conflicts across the continent. They have been targeted through sexual violence as a tactic of war, kidnapped and instrumentalized by terrorist groups, and been limited by attitudes that marginalize their voices in conflict resolution. This is despite the fact that women's participation and engagement in conflict resolution efforts are likely to contribute to a more sustainable peace.

UN peacekeeping has provided an important vehicle for progressing the WPS agenda, with mandates focused on strengthening women's participation in peace processes, ensuring the protection of women and girls, and integrating gender considerations into the approach of missions aimed at building sustainable peace. ${ }^{5}$ These missions have subsequently influenced efforts in parts of the continent to improve women's equality and strengthen their participation in the security sector, government, and political life. Research has shown that peacebuilding is less likely to succeed without the participation and consideration of women, and that gender inequality can be an indicator of conflict. ${ }^{6}$

Consequently, the role of UN peace operations in advancing WPS is worthy of further examination when it comes to examining lessons for peacebuilding efforts in Africa.

This chapter explores the opportunities and challenges that emerge from the efforts of UN peacekeeping missions advancing WPS in Africa. 
The first section examines how UN peacekeeping missions can advance WPS and whether these efforts within Africa have aligned with the efforts of continental, regional, and national approaches in Africa to build peace through women's participation and the integration of gender perspectives. The second section draws on the case studies of Liberia and South Sudan, as past and present hosts of UN peacekeeping missions, to highlight some of the different opportunities and challenges that are presented through the deployment of UN peacekeeping missions when it comes to furthering WPS. And the third section identifies some opportunities, limits, and constraints of UN peacekeeping as a tool to advance WPS, particularly when assessed against many of the initiatives already underway on the continent and the different types of reforms required at the national and subnational level to support implementation.

\section{Catalyzing Women, Peace, and Security through UN Peace Operations in Africa}

The women, peace, and security agenda has been codified through the adoption of ten resolutions by the UN Security Council over the last two decades. ${ }^{7}$ Yet efforts to link women's participation and engagement in conflict prevention efforts, as well as their protection, had been underway across the globe for decades before it came to the fore of the Security Council. Women-led civil society organizations had been championing a feminist peace agenda and their right to have a voice in such discussions long before the adoption of Resolution 1325. Indeed, the resolution had some origins in the work of African feminists and regional institutions on the continent in the years prior. As Toni Haastrup notes, the current Special Envoy on WPS for the African Union, Bineta Diop, spearheaded this work as the founder of Femmes Africa Solidarite. The WPS agenda is consequently considered by some to have been midwifed by Africa, with the adoption of the Windhoek Declaration in May 2000, which was championed by Namibia and laid the foundations for the comprehensive globalization of the agenda. ${ }^{8}$

Early lessons on the value and importance of women's participation and the consideration of gender perspectives in efforts to address conflict had emerged from some of the peacekeeping missions deployed in the decades prior to the adoption of Resolution 1325. But as the Windhoek Declaration noted, women had been "denied their full role in these efforts" and the gender aspects had "not been adequately addressed." 
The Declaration identified a number of reforms and improvements related to UN peacekeeping that were included in Resolution 1325, such as urging an expanded role and contribution for women through their participation in peacekeeping missions (including their appointment into senior leadership positions), and integrating gender expertise into peacekeeping missions through training and a gender component.

With more than a dozen UN peace operations deployed to the African continent since the adoption of Resolution 1325, peacekeeping has consequently served as a modest vehicle for operationalizing some aspects of the agenda through WPS in Africa. ${ }^{10}$ Similarly, African troop and police contributions to UN peacekeeping missions have offered an important vehicle for operationalizing aspects of the agenda through fostering women's participation and delivering training on integrating gender considerations. Yet those efforts have yielded mixed results, reflecting some of the broader challenges. There have also been limits with regard to how effectively peacekeeping missions have worked to build on existing national and local processes so that they are likely to be sustainable beyond the deployment of the peacekeeping mission.

\section{Evolution of Women, Peace, and Security in Peacekeeping}

Efforts to integrate different aspects of the WPS agenda into the mandates of UN peacekeeping missions have progressed significantly over the last two decades. When the Security Council authorized the deployment of the UN Mission in Sierra Leone (UNAMSIL) in 1999, it simply included a reference to the importance of training on "child and genderrelated provisions." As the adoption of a suite of resolutions on WPS has expanded, so has the initiative of the Security Council to include more detailed and specific provisions in its mandates, for instance to:

i. Address a wider range of different provisions to respond to women's protection needs, including from sexual and gender-based violence through mechanisms such as women's protection advisors;

ii. encourage host authorities to facilitate women's participation in electoral and political processes;

iii. consider women's needs in disarmament, demobilization, and reintegration processes; 
iv. increase women's participation in the security sector (including through improved representation of women in peacekeeping missions); and

v. more comprehensively integrate gender into all aspects of the work of peacekeeping missions (including through the deployment of gender advisers).

The significant number of UN peacekeeping missions deployed across the African continent over the last two decades has resulted in their use as a driver for WPS in some country-specific contents. For instance, missions have included mandates to:

i. Protect women from physical violence and the widespread use of rape and sexual violence as a weapon of war (e.g., MONUSCO in the Democratic Republic of the Congo and UNMISS in South Sudan);

ii. elevate the voices of women and civil society actors who may have been largely absent from government and the security sector (e.g., UNMIL in Liberia and UNOCI in Côte d'Ivoire); and

iii. ensure that women have a meaningful voice in peace forums and negotiations (e.g., MINUSCA in the Central African Republic).

In many instances, these efforts have been complemented by the work of regional and sub-regional organizations on the continent, whether it be through engagement in peace processes, joint United Nations-African Union (AU) visits by envoys, or the work of AU peace operations, which have mirrored many of the approaches of UN peacekeeping missions. For instance, in AMISOM "gender" is one of the six units of the civilian component. While these efforts have been directed at advancing women's participation and gender equality, they also contribute to furthering the sustainability and likelihood of peace long after a peacekeeping mission has transitioned and departed the country. ${ }^{11}$

The "Declaration of Shared Commitments on UN Peacekeeping Operations," agreed to by more than 150 members states and regional organizations, including 41 African Union members and the African Union Commission, captures many of these developments on WPS and commits to ongoing reforms. It does so in four areas: 
i. Ensuring the full, equal, and meaningful participation of women in all stages of the peace processes;

ii. systematically integrating a gender perspective into all stages of analysis, planning, implementation and reporting;

iii. increasing the number of civilian and uniformed women in peacekeeping at all levels and in key positions; and

iv. tailored, context-specific peacekeeping approaches to protecting civilians, in relevant peacekeeping operations, emphasizing the protection of women and children in those contexts. ${ }^{12}$

If implemented effectively, through prioritization, member state commitment, and sufficient resourcing, these measures will ensure that UN peacekeeping missions advance women's role in peace and security in their countries of deployment. Efforts to work closely with the UN Country Team (UNCT) when it comes to gender may also be critical in supporting national efforts. But there are still limits as to how far such initiatives may influence domestic reforms within their countries of deployment, as ultimately it is up to the host authorities to ensure that these reforms are being integrated through governance, justice, and the work of the security sector. For those efforts to be sustainable, peace operations must promote local, national, and regional ownership of the WPS agenda.

\section{Intersection with Continental, Regional, and Domestic Approaches}

The African Union has taken a leading role in implementing the WPS agenda in parallel with the developments globally through the UN Security Council. The formation of the African Union, building on the Organization of African Unity (OAU), contemporaneously with the adoption of Resolution 1325, meant that many of the African Union's foundational documents and institutions incorporated aspects of the WPS agenda into their formation. ${ }^{13}$ For instance, gender equality and female participation are included in the African Union's founding documents including the African Union Constitutive Act (2002). As Haastrup notes, Africans have been engaged in WPS from the beginning, therefore "it is thus unsurprising that the African Union has also taken up the discourse that aims to prioritize gender perspectives in the institutionalization and practice of peace and security on the continent."14 
In the last twenty years, the African Union has institutionalized WPS and ensured it is embedded across a range of continental, regional, and national policy instruments. ${ }^{15}$ In 2014, the Chair of the AU Commission appointed a Special Envoy on Women, Peace, and Security, with a mandate "to promote and echo the voices of women in conflict prevention, management and resolution, as well as advocate for the protection of their rights, including putting an end to impunity on sexual and genderbased violence."16 The African Union has developed a Gender Policy (2009) and a strategy for Gender Equality and Women's Empowerment (2017-2027). In 2017, the AU launched the Network of African Women in Conflict Prevention and Mediation (Femwise). The Peace and Security Commission continues to hold open sessions on women, peace, and security.

The continent has, at times, been lauded for the levels of women's political representation as well. For instance, Rwanda continues to have over 60 percent representation of women in parliament, a figure of envy for many in Europe and the West. Countries such as Kenya have constitutional quotas for women's representation (one third) in appointed and elected bodies. There have also been efforts to implement quotas as part of peace agreements. For example, the Revitalized Agreement on the Resolution of the Conflict in South Sudan requires 35 percent women's representation in governance and transition structures in South Sudan. But results have been mixed, with many targets continuing to fall short and women being negatively impacted in their efforts to engage in political life.

Many countries have also demonstrated political commitment to WPS through the development of National Action Plans (NAPs). As of 2019, 23 African member states have adopted NAPs on WPS. ${ }^{17}$ Similarly, at the regional level, the Economic Community of West African States (ECOWAS), the Intergovernmental Authority on Development (IGAD), the Mano River Union, and the Great Lakes Region have all adopted regional action plans. Yet as the African Union Commission has noted, implementation often remains poor, with NAPs being viewed as an end for the achievement on WPS, rather than a means to transform the lives of women. ${ }^{18}$ Several of the countries that have developed NAPs have hosted UN peacekeeping missions, with some working with the UN peacekeeping mission to develop their NAP (e.g., Liberia). As Sabrina Karim and Kyle Beardsley argue, there is some evidence that peacekeeping missions can encourage the creation of NAPS that focus on "domestic 
gender reforms."19 But like the flaws identified in other NAPS, their effectiveness and sustainability require political will, financial support, and accountability mechanisms. ${ }^{20}$ This has often been in short supply. Nonetheless, there are risks that UN peacekeeping missions might overlook the already existing mechanisms on the continent for addressing women's participation, their engagement in conflict prevention, and their protection.

\section{Furthering Women, Peace and Security Through UN Peacekeeping Missions: Case Studies}

Each UN peacekeeping mission deployed to the African continent offers different lessons when it comes to examining efforts to progress WPS. This section examines two different mission contexts-UNMIL in Liberia and UNMISS in South Sudan-to identify some of the different opportunities and challenges for advancing gender equality and furthering the participation of women in politics and the security sector. Each case study represents a mission at different stages (one transitioned, one still deployed), different conflict situations (one emerging from civil war, one a newly independent nation now grappling with the consequences of civil war), and different geographic locations.

\section{Liberia: Lessons from Integrating Gender and Transitions}

UNMIL completed its deployment in March 2018, after close to 15 years on the ground. UNMIL had deployed in October 2003, following the signing of the August 2003 Comprehensive Peace Agreement. Liberia had been ravaged by civil war throughout the 1990s. What makes UNMIL such an interesting case study, is that it was one of the first missions to incorporate significant provisions from Resolution 1325, following its adoption a few years earlier. As a result, the mandate for UNMIL picks up on many of the themes that were included in that resolution. Consequently, UNMIL has been viewed as one of the more successful missions when it comes to implementing key provisions of the WPS agenda. ${ }^{21}$ Throughout the fifteen years that the mission was deployed, it supported Liberia's efforts to advance WPS domestically in several ways. This section will examine the mission's role in facilitating women's participation in government and politics, advocating and modeling a role for women in the security sector, and facilitating processes 
to develop a national and domestic approach through the development of Liberia's first National Action Plan on WPS.

Women bore a significant brunt of the conflict throughout the 14year civil war in Liberia. The economic decline had limited their rights, there was widespread victimization making women more susceptible to sexual and gender-based violence, and women had lost critical access to different types of infrastructure across society, disempowering them. ${ }^{22}$ The first mandate authorizing the deployment of UNMIL in October 2003 consequently included a heavy focus on women's protection from violence. Resolution 1509 deplored "all violations of human rights, particularly atrocities against civilian populations, including widespread sexual violence against women and children," and referred to the importance of considering the "special needs of child combatants and women" in terms of disarmament, demobilization, reintegration and rehabilitation programs, as well as protecting and promoting human rights. Perhaps most importantly, it reaffirmed "the importance of a gender perspective in peacekeeping operations and post-conflict peace-building in accordance with resolution 1325 (2000), recalled the need to address violence against women and girls as a tool of warfare, and encouraged UNMIL as well as the Liberian parties to actively address these issues." 23 This mandate enabled the establishment of a gender adviser function within the mission, which facilitated ongoing initiatives across the mission.

Despite the disproportionate impact that the civil war in Liberia had on woman, this had not stopped their efforts to ensure their voices were heard when it came to the political processes in the country. Prior to the deployment of UNMIL in 2003, women had engaged through initiatives such as the Liberian Women Initiative, the Mano River Women Peacebuilding Network, and Women in Peacebuilding Network, to develop constituencies of support and insert themselves into the peace negotiations. $^{24}$ This ultimately meant that the will of women was captured in the Comprehensive Peace Agreement, which also set quotas for representatives in the Transitional Legislative Assembly. Similarly, the Ministry of Gender and Development was established in 2001, serving "as the primary vehicle on all matters affecting the protection, promotion, participation and advancement of women in Liberia." 25

Notably, much of the groundwork on women's participation and gender mainstreaming had been laid before the deployment of a UNMIL. ${ }^{26}$ Many of the reforms that contributed to the environment that fostered women's participation and contributed to the election of 
the continent's first female President in 2005, for instance, is therefore attributable to the work of women's civil society organizations in Liberia, although this was amplified by the work of UNMIL in investing in gender training and providing support to the Ministry of Gender. ${ }^{27}$ Notably, as the best practices study by the UN indicated in 2009, the key to success up until that point had been a "multi-stakeholder" process, which engaged with the government, civil society organizations, and community-based organizations, "harnessing the existing political will for gender issues in the country." 28 The emergence of key women leaders was also fundamental to these efforts.

Also notable was the focus on women's participation in the security sector in UNMIL's mission mandate. UNMIL is often lauded for being one of the first missions to facilitate the deployment of an allfemale Formed Police Unit (FPU) from India, with this being identified as an important enabling factor in encouraging and modeling women's participation in the security sector. ${ }^{29}$ However there are mixed views on how effective the deployment was in encouraging greater participation of women in the security sector and engaging with local women, given that restrictions on their mobility and interactions may have limited them reaching their potential. ${ }^{30}$ As Karim argues, while the deployed FPUs may have contributed to important overall goals within the peacekeeping mission (such as increased ratios of female peacekeepers and their engagement in protection efforts), those achievements still largely focused on largely "feminized work," meaning female peacekeepers continue to face barriers to their engagement. ${ }^{31}$ Consequently, if these deployments of female peacekeepers are to serve as role models, then it is a narrow scope for the women seeking to serve in the Liberian security sector.

Efforts to increase women's participation in the national police in Liberia extended beyond simply mirroring the representation of female peacekeepers in missions. UNMIL worked closely with the Liberian National Police (LNP) to deliver on targets for women's participation, and develop educational support programs to ensure women met the basic standard for qualification and recruitment. ${ }^{32}$ Numbers consequently increased, although efforts to generate more sustainable reforms remain hampered by many of the challenges facing women in defense and police sectors globally, including family pressures, pregnancy, and health issues. Nonetheless, UNMIL's engagement expedited efforts to increase the participation of women in the security sector, including through working 
with donors and other partners to implement security sector reform programs.

In support of more comprehensive engagement on WPS, UNMIL also engaged in supporting the development of Liberia's first National Action Plan on WPS. In fact, the plan, adopted in 2009, recognized the support not only of UNMIL, but other UN agencies and donor countries in supporting its development. While there has been no second national version to follow after the NAPs initial period of 2009-2013, Liberia now has in place 11 localized plans on WPS. ${ }^{33}$ Although NAPs are not the only indicator of government commitment to WPS (and indeed, can often serve as a smokescreen to conceal other failings), the presence of a NAP is often viewed as a starting point.

There is no doubt that UNMIL and the engagement of stakeholders brought resources to bear that supported Liberia's engagement on WPS over the last two decades, demonstrating that UN peacekeeping missions, in particular, can contribute to the advancement of WPS in countries affected by conflict. For Liberia, the challenge will be ensuring that those gains are sustained going forward.

\section{South Sudan: Navigating Politics and Protection Concerns}

Women were actively engaged in the independence movement for South Sudan. However, since then, they have continued to struggle to have a more formal role in peace negotiations as the country has struggled to resolve decades of internal divides, particularly since the outbreak of civil war in the country in December 2013.

UNMISS was established in July 2011, following the country's independence. Unfortunately, after decades of conflict with the north, South Sudan fell into civil war in December 2013, and women have disproportionately suffered as a consequence, through mass displacement and unprecedented levels of sexual violence, with the latter often being used to reward fighters for their engagement in the conflict. ${ }^{34}$ With these developments, UNMISS' WPS mandate shifted from an initial focus on women's participation and engagement in political processes, to one that is focused on women's protection. ${ }^{35}$ With that change, the mission also disengaged in its capacity-building efforts with the host government as it had largely become complicit in human rights abuses and atrocities, including against women. Needless to say, the operating environment for UNMISS when it comes to advancing WPS has been challenging. 
Efforts to progress women's engagement in political participation and representation across government have, similarly, continued to face obstacles throughout the deployment of UNMISS. Women have continued to be underrepresented in formal peace negotiations, despite commitments to minimum levels of women's representation as part of transitional governance arrangements and peace agreements. Culturally, some of the gendered roles continue to drive the dynamics of localized conflicts, with the underage marriage of girls common and bride price (an amount paid by the husband to a woman's family) driving cattle-raiding and conflict across the country. Women also have considerably less access to education, meaning an overwhelming proportion of the female population is illiterate. Nonetheless, women have been actively engaged in many informal and localized conflict resolution efforts across the country, despite their lack of access to formal peace processes. ${ }^{36}$

The Security Council has recognized that many barriers exist to the full realization of Resolution 1325 in South Sudan:

"[they would] only be dismantled through dedicated commitment to women's empowerment, participation and human rights, concerted leadership, consistent information and action, and support, to build women's engagement in all levels of decision-making, and through ensuring that the full and meaningful participation and involvement of women in all spheres of political leadership." 37

Yet part of the challenge for UNMISS is that the government's largely authoritarian approach continues to limit the voice of women in peace efforts. Women-led organizations have to formally register with the government. With many of them being viewed as opposed to government, often they are stymied. ${ }^{38}$ Following a march in the capital, Juba in 2018, many of the leaders of different women's groups were summoned and subjected to threats and intimidation by the government's security agencies. UN peacekeeping can have a big role in strengthening the advocacy of women's groups in these environments, through their high-level engagement with the government.

While the current mission mandate, renewed through Resolution 2459 , includes a focus on women's participation, particularly the requirement for 35 percent women's representation in parliament as part of the most recent peace agreement, there is considerably more language devoted to sexual and gender-based violence and women's protection by 
the mission. Impunity, lack of established rule-of-law mechanisms, and a poorly governed and supported security sector, have contributed to an environment where sexual violence is rife in parts of the country. ${ }^{39}$ Through its protection of civilians mandate, UNMISS has afforded some protection to vulnerable groups, including women, in designated sites (referred to as "POC sites" or protection of civilian sites), and in areas where it has been able to project force. However, without significant reforms across the security and justice sectors, as well as political commitment, any initiatives undertaken by UNMISS are unlikely to remain sustainable beyond the deployment of the mission.

Like many countries on the continent, South Sudan has also developed a National Action Plan on WPS, with a duration from 2015-2020. Similar to Liberia, the plan was developed with the support and consultation of the peacekeeping mission, as well as other donors and stakeholders. But the plan has had a very limited impact on addressing some of the challenges that women continue to face.

\section{Conclusions}

Over the last two decades, UN peacekeeping operations have offered an important vehicle to facilitate the engagement of countries in Africa on women, peace, and security. They have:

i. Supported efforts to amplify women's voices in political processes, in government, and as part of conflict resolution initiatives;

ii. modeled the importance of engaging women in the security sector and positions of leadership;

iii. supported host governments in their efforts to respond to women's protection needs (and intervened when they have been unwilling to do so); and

iv. sought to mainstream the importance of gender across programs directed a long-term peace, including disarmament, demobilization, and reintegration, reform of the security sector, justice and the rule of law, and longer-term peacebuilding initiatives.

Of course, there are limits to what UN peacekeeping can and should do when it comes to advancing women, peace, and security. Peacekeeping is not a panacea when it comes to WPS and has its own flaws in its effort 
to integrate WPS across its work. Peacekeepers often come with a limited understanding of the cultural context they are deploying into or the local and regional mechanisms that may be available to them when it comes to WPS. Furthermore, there are some countries that are actively working against the work of gender advisers in peacekeeping missions, despite the successes that these roles and functions have been shown to have in contexts such as Liberia. As the Global Study on Resolution 1325 identified in $2015,{ }^{40}$ these measures are often not prioritized. Gender advisers are not deployed at appropriate levels of seniority, women's civil society organizations are not funded adequately and many of the governments where UN peacekeeping missions have been deployed have continued to trample on women's rights and their role in society. These are all different challenges that countries are likely to continue to face, long after a peacekeeping mission has transitioned and departed.

It is difficult to measure progress when it comes to WPS in domestic contexts. Efforts to put in place effective monitoring and evaluation systems as part of the development of National Action Plans have remained a challenge for many countries. Nonetheless, there are some elements and areas of change that reflect whether a country is moving forward, including the levels of women's participation across political, electoral, and governance institutions, whether the levels of their engagement in the security sector are increasing (and if so, whether this is taking place at different levels and roles throughout the organization), and the overall perceptions of women's security across the country, including whether they are feeling safe, whether there is impunity, and whether their rights are being upheld. This is not an exhaustive list. There are many other indicators that can be drawn on. ${ }^{41}$ But these highlight some of the pillars where peacekeeping missions tend to engage when it comes to participation, prevention, and protection.

The case studies of Liberia and South Sudan highlight some of the different challenges when it comes to UN peacekeeping missions supporting countries' commitments to WPS. UNMIL and UNMISS had different priorities and experiences in garnering government support and the engagement of civil society. Even with the progress that has been made in Africa at the continental and regional level, each approach by UN peacekeeping missions to WPS at the national and local level in-country must be context-specific to the circumstances on the ground. 
Ultimately, UN peacekeeping missions offer an important but limited vehicle for advancing WPS on the African continent. Efforts will need to be increasingly focused on regional and sub-regional approaches to conflict. Similarly, the African Union will increasingly need to invest in its own regional and sub-regional peace operations, including some of the gender mechanisms that have already been deployed in contexts such as Somalia and elsewhere. Africa is well placed with a range of regional and continental mechanisms available to facilitate women's engagement across the continent. Countries on the continent have shown a willingness to lead and engage on the agenda, including through the work of the UN Security Council and multilateral institutions. Perhaps most importantly, women's civil society organizations have shown the way when it comes to leadership and advocacy to take forward reforms to advance women's participation and amplify their voices in peacebuilding initiatives on the continent. Those lessons and experiences offer an important roadmap for the way forward for UN peacekeeping as it continues to work with African partners to advance women's peace and security.

\section{Key Recommendations}

1. Listen to women, then engage, and build upon the networks that alveady exist in civil society organizations across the country. This requires ongoing, meaningful engagement with women. Women need to have influence and be heard. This should be captured in mission assessment and planning processes, as well as peacekeeping mission mandates. It is imperative that UN peacekeeping missions avoid becoming another form of colonialism that neglects the views of those they seek to serve, particularly when it comes to women and their role in society.

2. African governments and civil society need to be involved at the outset of programs focused on Women, Peace, and Security by UN peacekeeping missions. Missions need to ensure that programs they develop-often in conjunction with UN country teams, agencies, and international and local non-governmental organizations-build sustainable approaches to WPS within institutions across government and mechanisms to engage effectively with civil society. National Action Plans on WPS offer one approach to facilitate this engagement. 
3. Ensure that missions are making themselves obsolete in order to advance gender equality. This requires that equality becomes "business as usual" for the country's political leaders. In some countries, there is still much to do. But where leaders are not supportive of this agenda, regional and continental mechanisms to compel change need to be enforced.

\section{Notes}

1. United Nations Security Council, Letter dated 12 July 2000 from the Permanent Representative of Namibia to the United Nations address to the Secretary-General, UN Doc S/2000/693, July 14, 2000.

2. United Nations Transition Assistance Group (UNTAG) was deployed to Namibia from April 1989 to March 1990.

3. United Nations Security Council, Letter dated 12 July 2000 from the Permanent Representative of Namibia to the United Nations.

4. Sabrina Karim and Kyle Beardsley, Equal Opportunity Peacekeeping: Women, Peace and Security in Post-Conflict States (Oxford University Press, February 2017), 14.

5. Lisa Sharland, Women, Gender and the A4P Agenda: An Opportunity for Action?, Background Paper, Challenges Annual Forum 2018.

6. World Bank and United Nations, Pathways for Peace: Inclusive Approaches to Preventing Violent Conflict (Washington, DC: World Bank, 2018), xxiii.

7. Resolutions 1325 (2000); 1820 (2009); 1888 (2009); 1889 (2010); 1960 (2011); 2106 (2013); 2122 (2013); 2242 (2015), 2467 (2019), and 2493 (2019).

8. Toni Haastrup, "WPS and the African Union," in The Oxford Handbook on Women, Peace and Security, Sara E. Davies and Jacqui True (eds.) (New York, NY: Oxford University Press, 2019), 378; and African Union Commission, Implementation of the Women, Peace and Security Agenda in Africa, Addis Ababa, 2016, 6.

9. United Nations Security Council, Letter dated 12 July 2000 from the Permanent Representative of Namibia to the United Nations, 2.

10. Missions that have deployed to the continent since the adoption of UN Security Council Resolution 1325 include MINUCI (Côte d'Ivoire), UNMIL (Liberia), UNOCI (Cote d'Ivoire), ONUB (Burindi), UNMIS (Sudan), UNAMID (Darfur), MINURCAT (Central African Republic/Chad), MONUSCO (Democratic Republic of the Congo), UNMISS (South Sudan), UNISFA (Abyei), MINUSMA (Mali) and MINUSCA (Central African Republic). 
11. United Nations-World Bank, Pathways for Peace: Inclusive Approaches to Preventing Violent Conflict (2018), 117.

12. United Nations, Declaration of Shared Commitments on UN Peacekeeping Operations (2017), paras 8 and 9.

13. Haastrup, "WPS and the African Union," 378.

14. Ibid., 379.

15. African Union Commission, Implementation of the Women, Peace and Security Agenda in Africa (July 2016), 6.

16. African Union Commission, Continental Results Framework-Monitoring and Reporting on the Implementation of the Women, Peace and Security Agenda in Africa (2018-2028) (Addis Ababa, 2019), 3.

17. Côte D'Ivoire, Uganda, Liberia, the Democratic Republic of the Congo, Sierra Leone, Ghana, Rwanda, Guinea-Bissau, Guinea, Burundi, Senegal, Burkina Faso, The Gambia, Mali, Togo, Nigeria, Central African Republic, Kenya, South Sudan, Niger, Angola, Cameroon, and Mozambique.

18. African Union Commission, Continental Results Framework-Monitoring and Reporting on the Implementation of the Women, Peace and Security Agenda in Africa (2018-2028) (Addis Ababa, 2019), 4.

19. Karim and Beardsley, Equal Opportunity Peacekeeping, 20

20. United Nations, Preventing Conflict, Transforming Justice, Securing the Peace: A Global Study on the Implementation of United Nations Security Council Resolution 1325 (2015), 14.

21. Sabrina Karim, "Delivering WPS Protection in All Female Peacekeeping Force: The Case of Liberia," in The Oxford Handbook on Women, Peace and Security, The Oxford Handbook on Women, Peace and Security, Sara E. Davies and Jacqui True (eds.) (New York, NY: Oxford University Press, 2019), 451.

22. United Nations, Gender Mainstreaming in Peacekeeping Operations: Liberia 2003-2009, 3.

23. United Nations S/RES/1509, operational paragraph 11.

24. United Nations, Gender Mainstreaming in Peacekeeping Operations: Liberia 2003-2009, 3.

25. Ibid., 4.

26. Although ECOWAS had been engaged in peace operations in the country through ECOMOG at the time.

27. Karim, "Delivering WPS Protection in All Female Peacekeeping Force," 451 .

28. United Nations, Gender Mainstreaming in Peacekeeping Operations: Liberia 2003-2009, 30. 
29. United Nations, "In a First for UN peacekeeping, All-Female Police Unit Arrives in Liberia," January 30, 2007, https://news.un.org/en/story/ 2007/01/207362-first-un-peacekeeping-all-female-police-unit-arrives-lib eria.

30. Karim, "Delivering WPS Protection in All Female Peacekeeping Force," 458.

31. Ibid.

32. See, for instance, Laura Bacon, Liberia's Gender Sensitive Police ReformStarting from Scratch? Improving Representation and Responsiveness (UNU Wider, October 2013); and United Nations, Gender Mainstreaming in Peacekeeping Operations: Liberia 2003-2009, 30.

33. United Nations, Report of the Secretary General, Women and Peace and Security, S/2019/800, October 9, 2019, 24.

34. Helen Kezie-Nwoha and Juliet Were, "Women's Informal Peace Efforts: Grassroots Activism in South Sudan," CMI Brief Number 7, November 2018.

35. United Nations Security Council Resolution 2996 (2011).

36. Kezie-Nwoha and Were, "Women's Informal Peace Efforts: Grassroots Activism in South Sudan."

37. UN Resolution 2459.

38. Kezie-Nwoha and Were, "Women's Informal Peace Efforts: Grassroots Activism in South Sudan."

39. UN News, "Endemic Sexual Violence Surging in South Sudan: UN Human Rights Office," February 15, 2019, https://news.un.org/en/ story/2019/02/1032831.

40. See United Nations, Preventing Conflict, Transforming Justice, Securing the Peace: A Global Study on the Implementation of United Nations Security Council Resolution 1325, 2015, 279.

41. Georgetown Institute for Women, Peace and Security and Peace Research Institute Oslo, Women, Peace and Security Index 2019/20: Tracking Sustainable Peace through Inclusion, Justice, and Security for Women. Washington, DC, 2019. 
Open Access This chapter is licensed under the terms of the Creative Commons Attribution 4.0 International License (http://creativecommons.org/licenses/ by $/ 4.0 /$ ), which permits use, sharing, adaptation, distribution and reproduction in any medium or format, as long as you give appropriate credit to the original author(s) and the source, provide a link to the Creative Commons license and indicate if changes were made.

The images or other third party material in this chapter are included in the chapter's Creative Commons license, unless indicated otherwise in a credit line to the material. If material is not included in the chapter's Creative Commons license and your intended use is not permitted by statutory regulation or exceeds the permitted use, you will need to obtain permission directly from the copyright holder.

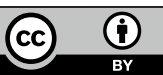

